\title{
A GIS-based approach for identifying suitable sites for rainwater harvesting technologies in Kasungu District, Malawi
}

\author{
F Nyirenda', A Mhizha², W Gumindoga ${ }^{2}$ and A Shumba ${ }^{3}$ \\ ${ }^{1}$ Kasungu Agricultural Development Division, Private Bag 28, Kasungu, Malawi \\ ${ }^{2}$ Department of Construction and Civil Engineering, University of Zimbabwe, Harare, Zimbabwe \\ ${ }^{3}$ Department of Geomatics Engineering, University of Zimbabwe, Harare, Zimbabwe
}

A GIS-based approach for identifying suitable sites for rainwater harvesting (RWH) technologies was developed and applied in Kasungu District, Malawi. Data were obtained from reports, socio-economic survey documents of the area and maps. Field surveys were conducted in the villages of Chipala Extension Planning Area (EPA), in order to identify and evaluate the performance of existing RWH interventions, and determine factors for locating suitable areas for RWH. Observed soil moisture content was used to assess the water retention performance of the prevalent RWH technologies: contour tied ridging and soil mulching. A GIS-based Soil Conservation Service Curve Number (SCS-CN) method was used to map runoff potential for areas with RWH technologies, using physical factors of rainfall, land use, soil type and slope to estimate runoff potential. This was then integrated in a GIS database, with social-economic factors in the form of household income level and environmental factors, including impacts of implementing RWH, to determine the suitability of land areas for RWH in Kasungu District. One way analysis of variance (ANOVA) was used to test the impact of identified technologies by comparing the moisture content measurements for each of the identified technologies at $5 \%$ level of significance. The ANOVA results showed a statistically significant difference in the moisture measurements for the three technologies identified $(P<0.05)$. The RWH suitability map for the study area showed that $0.2 \%$ of the area considered had very high potential, $33.5 \%$ high, $55.9 \%$ moderate, $10.1 \%$ marginal and $0.3 \%$ not suitable for in-field RWH. The model was verified by locating the existing RWH on the suitability map obtained from GIS: $81 \%$ of RWH were located in the highly and moderately suitable areas whilst only $13 \%$ were located in areas of low suitability. Hence the developed model can reliably be used to predict potential areas for RWH.

\section{INTRODUCTION}

Agriculture is the major source of livelihoods for about $70 \%$ of the population in semi-arid areas (Rockström et al., 2010). These livelihood activities face many constraints due to erratic rainfall patterns which could be lower than $500 \mathrm{~mm}$ /year in many cases. Rockström and Falkenmark (2015) recommended investing in rainwater harvesting (RWH) technologies for high agricultural production, due to improved moisture retention for crops. RWH is the process of intercepting and concentrating rainwater in order to increase water infiltration into the soil for direct use by plants or in reservoirs for later application when needed to mitigate dry spells (Mzirai and Tumbo, 2010).

The Ministry of Agriculture of Malawi through Land Resources Conservation Department (LRCD) has started to promote RWH on a broad scale, since RWH offers an alternative for Malawi to meet its food security needs. However, the implementation of RWH in Malawi has been faced with several challenges, such as excessive loss of water due to high rates of evaporation and seepage. The use of geospatial technologies, such as remote sensing (RS) and geographic information systems (GIS), has been found to be effective for identifying suitable areas for RWH (Kahinda et al., 2008; Jasrotia et al., 2009; Jha et al., 2014). GIS has been recommended for use in decision making for RWH. However, in Malawi the use of GIS in identification of suitable sites for RWH has not been practised and very little is documented (Nthara, 2020; Face of Malawi, 2013). Although the Government of Malawi has been promoting the implementation of RWH to improve the food security of rural people, this implementation has faced a lot of challenges, resulting in low adoption.

This study's main focus is to develop a GIS-based approach for identifying suitable sites for insitu rainwater harvesting technologies in Kasungu District of Malawi. In order to achieve this, the following specific objectives were identified:

- To identify and evaluate performance of existing rainwater harvesting (RWH) technologies in Kasungu District

- To establish factors for locating suitable areas for RWH interventions in Kasungu District.

- To integrate factors for locating and mapping suitable areas for RWH interventions in a GIS-based platform in order to locate land suitable for RWH in Kasungu District.

\section{MATERIALS AND METHODS}

\section{Study area}

Kasungu District is located approximately $127 \mathrm{~km}$ from Lilongwe, the capital city of Malawi (NSO Atlas, 2002). The District (Fig. 1) has a total area of $7878 \mathrm{~km}^{2}, 8.4 \%$ of the total land area

\section{CORRESPONDENCE}

F Nyirenda

\section{EMAIL}

nyirenda81fred@gmail.com

\section{DATES}

Received: 28 February 2020

Accepted: 20 July 2021

\section{KEYWORDS}

rainwater harvesting technologies geographic information systems Soil Conservation Service contour tied ridging soil mulching

\section{COPYRIGHT}

(c) The Author(s) Published under a Creative Commons Attribution 4.0 International Licence (CC BY 4.0) 


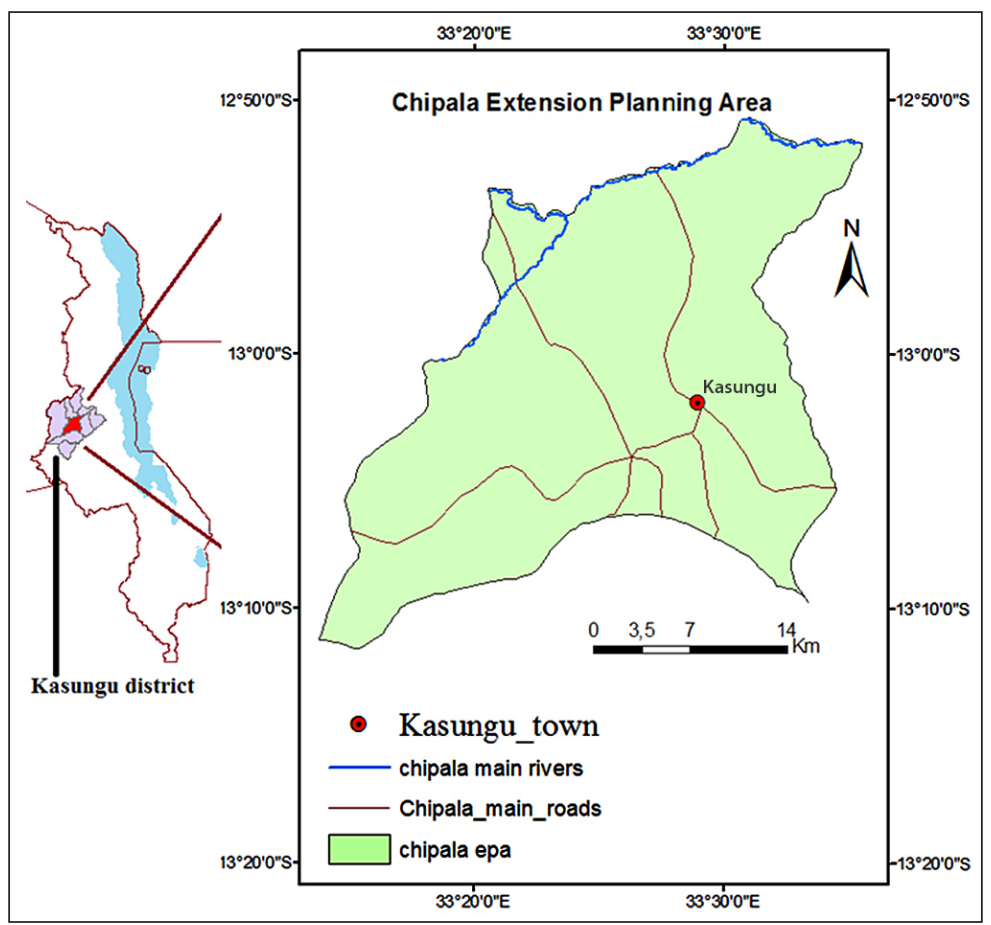

Figure 1. Location of the study area

of Malawi (Kasungu SEP, 2013). The District experiences an average minimum and maximum temperature of $12^{\circ} \mathrm{C}$ and $30^{\circ}, \mathrm{C}$ respectively, with rainfall averaging $750 \mathrm{~mm} \cdot \mathrm{year}^{-1}$. This rainfall is enough to support the production of most crops grown in the area, such as maize, tobacco and soya beans, but the main problem is the variation in the onset and distribution pattern of rainfall, which results in crop failure. The district was targeted for this research because of its uneven rainfall distribution patterns, which calls for the implementation of RWH technologies so as to overcome the effects of prolonged dry spells and ensure food security (Kasungu SEP, 2013). Kasungu District is divided into 8 agricultural zones called Extension Planning Areas (EPAs), namely, Chulu, Kaluluma, Chipala, Chamama, Lisasadzi, Mkanakhoti, Mtunthama and Santhe (Kasungu SEP, 2013). Kasungu SEP (2013) indicates that Kasungu District is dominated by agriculture as the major economic activity and source of livelihood. For this study Chipala EPA was targeted because farmers here have already started implementing RWH technologies.

\section{Field data collection}

\section{Field surveys}

A stakeholder survey was conducted to assess RWH implementation in the study area in order to identify existing RWH technologies. Open-ended questionnaires for key informants were used, which focused on extension officers and nongovernmental organizations (NGO) working in the area. Four villages were randomly selected for focus group discussions (FGDs). Relatively few farmers had implemented RWH in the area, hence it was difficult to identify households of the rainwater harvester from that of the non-harvester, prompting the use of the snowball identification method. Snowball identification is the method of sampling where identification of respondents is done by respondents who then refer researchers to other respondents (Atkinson and Flint, 2001). Farmer identification targeted those farmers who were currently implementing any type of RWH technology in their fields. Firstly, 8 farmers were identified with assistance from the extension worker who works in the area. Fellow farmers were able to know those who implemented RWH technologies because they frequently met during field days that were organized by government agricultural extension agents.
Pre-testing of the questionnaires was done with 5 respondents (about $10 \%$ of total targeted study respondents), which helped to identify challenges that would arise when administering the questionnaire in the field. The questionnaire was then revised to forestall these challenges. A total of 54 respondents, who were all household heads, were interviewed. This helped to generate a clear understanding of the different field characteristics and to access information on the RWH practices that a particular household implements. Coordinates for the locations of the fields of all respondents were recorded using a GPS.

\section{Soil moisture observation on selected RWH technologies}

Soil moisture data from fields with RWH technologies was obtained to assess performance of technologies and, together with physical, socio-economic and environmental factors of the areas where the RWH technologies are implemented, was used to determine suitable factors for assessing suitability. Fields for moisture observation were selected from 3 zones, denoted as A, B and C (Fig. 2); all the selected fields were under maize crops. From each zone, 3 fields were selected for observation: (i) field under contour tied ridging; (ii) field under mulching and (iii) field with no RWH technology acting as control field. This resulted in a total of 9 target fields for all 3 zones, as shown in Fig. 2.

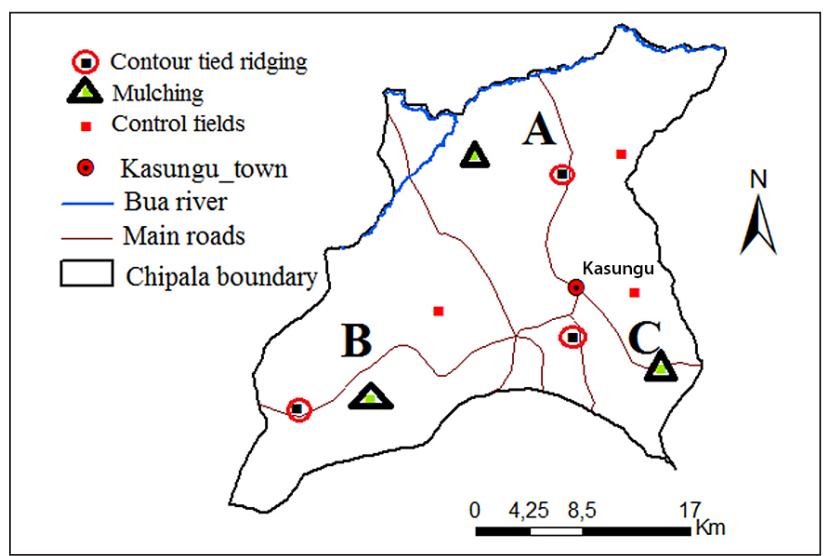

Figure 2. Chipala EPA showing soil sampling fields for moisture content 
Soil samples were taken randomly at 4 points in each field at a depth of $15 \mathrm{~cm}$ during 4 periods in the season (before rains had started, soon after rains had started and crops were planted, at mid-season and after harvest), which corresponded to 4 stages of crop growth, as recommended by Doorenbos and Pruitt (1977). The gravimetric method was used to estimate soil moisture as a percentage of dry mass, as described by Black (1965).

\section{Data for GIS-based integration of factors determining suitability of areas for RWH}

Data on physical factors affecting runoff generation potential, socio-economic factors affecting RWH implementation capacity, and environmental factors were needed as inputs into a GIS platform for determining suitability of areas for RWH. Runoff modelling simulates the volume of runoff that can be generated in the field and from external catchments and application directly into the soil profile, for moisture retention or storage for supplementary irrigation to crops during dry spells. The Soil Conservation Service Curve Number (SCS-CN) method was used to estimate the amount of runoff generated, which was then incorporated into the GIS model for identification of suitable sites for RWH. Climatic data, including rainfall data for 10 years (2005-2015) was sourced from the meteorological gauging stations in the district. Rainfall remote-sensing satellite data called Climate Hazards group Infrared Precipitation with Station (CHIRPS), which is a land-only climatic database of precipitation made available since early 2014, was downloaded for the period of 34 years from 1981-2015. It contains two different kinds of information: world climatology and satellite estimates (Katsanos et al., 2016). CHIRPS raster data for 34 years from 1981-2015 at monthly time-step was selected to be used in the runoff calculations using ArcGIS10.2.2. CHIRPS global raster map was resized from $25 \mathrm{~km}^{2}$ to $1 \mathrm{~km}^{2}$ pixel sizes, since the study area was much smaller as compared to the global scale. CHIRPS rainfall data were re-projected to enable overlay of the study area boundary map, and were further processed to clip the study area boundary map. Socio-economic data (household income level) were sourced from the Malawi National Statistics Office, while environmental data were sourced from the District Environmental Office and Forestry Office.

\section{Identification of areas suitable for RWH}

Locating suitable areas for RWH is a multi-objective and multicriteria process that is dependent on physical, socio-economic and environmental factors of a specific location. De Winnaar et al. (2007) reported that appropriate RWH technologies which are developed for a particular region cannot merely be replicated in another location. Therefore, in order to identify suitable areas for RWH, an area measured by pixel size of $30 \mathrm{~m}$ by $30 \mathrm{~m}$ was analysed for RWH suitability. The following steps were taken: (i) selection of factors, (ii) assessment of suitability levels for the factors, (iii) assignment of weights to the factors, (iv) collection of spatial data for the factors such as coordinates which supplemented information for generation of map layers, (v) developing a GIS-based model that combines all map layers through MCE process (weighted overlay), and (vi) generation of a suitability map. A detailed methodology is shown in Fig. 3 (adapted from Kadam et al., 2012).

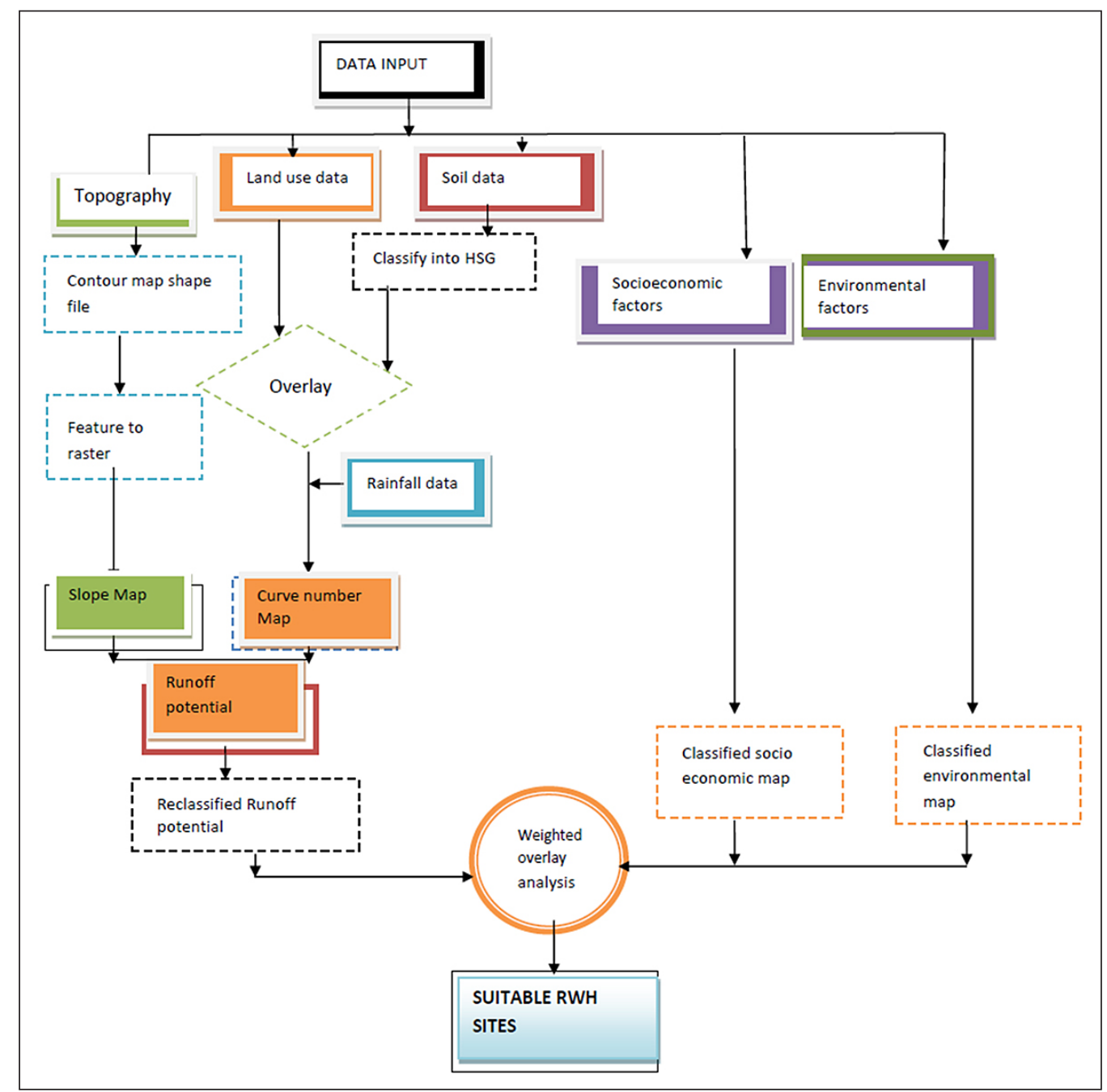

Figure 3. Methodology flow chat (Kadam et al., 2012) 


\section{Selection of factors for identifying potential sites for RWH}

Various factors were identified for RWH suitability: physical, socio-economic and environmental. These factors were scored into 5 suitability scores, $1,2,3,4$ and 5 , to enable integration.

\section{Physical factors}

\section{$\underline{\text { Rainfall }}$}

Rainfall was chosen as a factor because it is a critical factor for crop production. FAO (2003b) recommends the use of rainwater harvesting technology (RWHT) in areas receiving from $100 \mathrm{~mm}$ to $1000 \mathrm{~mm} \cdot$ year $^{-1}$ of rain. There is barely any productive waterbased activity in areas that receive less than $100 \mathrm{~mm} \cdot \mathrm{year}^{-1}$ of rain while there is no incentive to implement RWHT in areas with annual rains in excess of $1000 \mathrm{~mm} \cdot \mathrm{year}^{-1}$. Annual rainfall for the study area ranges from $734 \mathrm{~mm}$ to $942 \mathrm{~mm}$.

\section{Land use}

Different land uses result in different levels of runoff generation during rainfall (Jedhe, 2014), hence land cover was selected as a factor for identifying suitable sites for RWH. For instance, vegetation is a vital factor that affects surface runoff. Built-up areas tend to generate more runoff as compared to vegetated areas (Jha et al., 2014). This study focused only on in-situ (in-field) RWH and all built-up areas were thus considered unsuitable.

\section{Soil type}

In the study area, soils range from sandy clay loam to pure sandy soils, with soil depth ranging from less than $0.2 \mathrm{~m}$ to more than $0.75 \mathrm{~m}$ (Kasungu SEP, 2009). Soils with high water-holding capacity are generally suitable for RWH. Sandy soils are not suitable, therefore loamy soils are most suitable for RWH, unlike clay soils which are less suitable because of their low infiltration capacity and risk of waterlogging (Mbilinyi et al., 2014). The soil types in the study area were grouped into 4 hydrological soil groups: Group A - sand, loamy sand and sandy loam types of soils; Group B -silt, silt loam and loam soils; Group C - sandy clay loam soils; and Group D - clay loam, silty clay loam, sandy clay, silty clay and clay soils, as shown in Fig. 4c.
Slope

Critchley et al. (1991) indicated that RWH is not recommended for areas of slope $>5 \%$, especially due to the large quantities of earthworks required, which is costly. In-situ RWHT are more appropriate in areas having a flatter slope, but a slight slope is required for better harvesting of the runoff (Buraihi and Shariff, 2015). Therefore, in this study, slope was considered as a factor as well for identifying suitable areas for RWH shown in Fig. $4 \mathrm{~d}$.

\section{Socio-economic factors}

Socio-economic factors were considered as important for identifying suitable sites for RWH technologies since they affect farmers' decisions. The factors considered, such as income level, were derived from the National Statistical Data Portal, combined with household annual income level obtained through questionnaires, which facilitated the generation of the socio-economic map layer. Any household with an annual income exceeding MK 310250 (equivalent to 456 USD) was considered above the low-income group (poverty datum) (NSO, 2000) and was considered as more likely to successfully implement RWH as compared to a household whose annual income is below poverty datum (Baiyegunhi, 2015). A socio-economic layer was obtained by generating a point map from the location of farmers in each village and then interpolated using the inverse distance weighting technique of ArcGIS 10.2.2 shown in Fig. $5 \mathrm{a}$, as done by Nthuni et al. (2014). The map was classified and assigned suitability values based on the RWH suitability criteria used by Mwenge Kahinda et al. (2009) as shown in Table 1.

Table 1. RWH suitability ranking for socio-economic factors

\begin{tabular}{lccc}
\hline No. & $\begin{array}{c}\text { Socio-economic } \\
\text { class }\end{array}$ & $\begin{array}{c}\text { Annual income } \\
\text { (MK) }\end{array}$ & Suitability score \\
\hline 1 & Very low & $<50250$ & 1 \\
2 & Low & $50251-100500$ & 2 \\
3 & Medium & $100501-150750$ & 3 \\
4 & High & $150751-201001$ & 4 \\
5 & Very high & $>201001$ & 5 \\
\hline
\end{tabular}

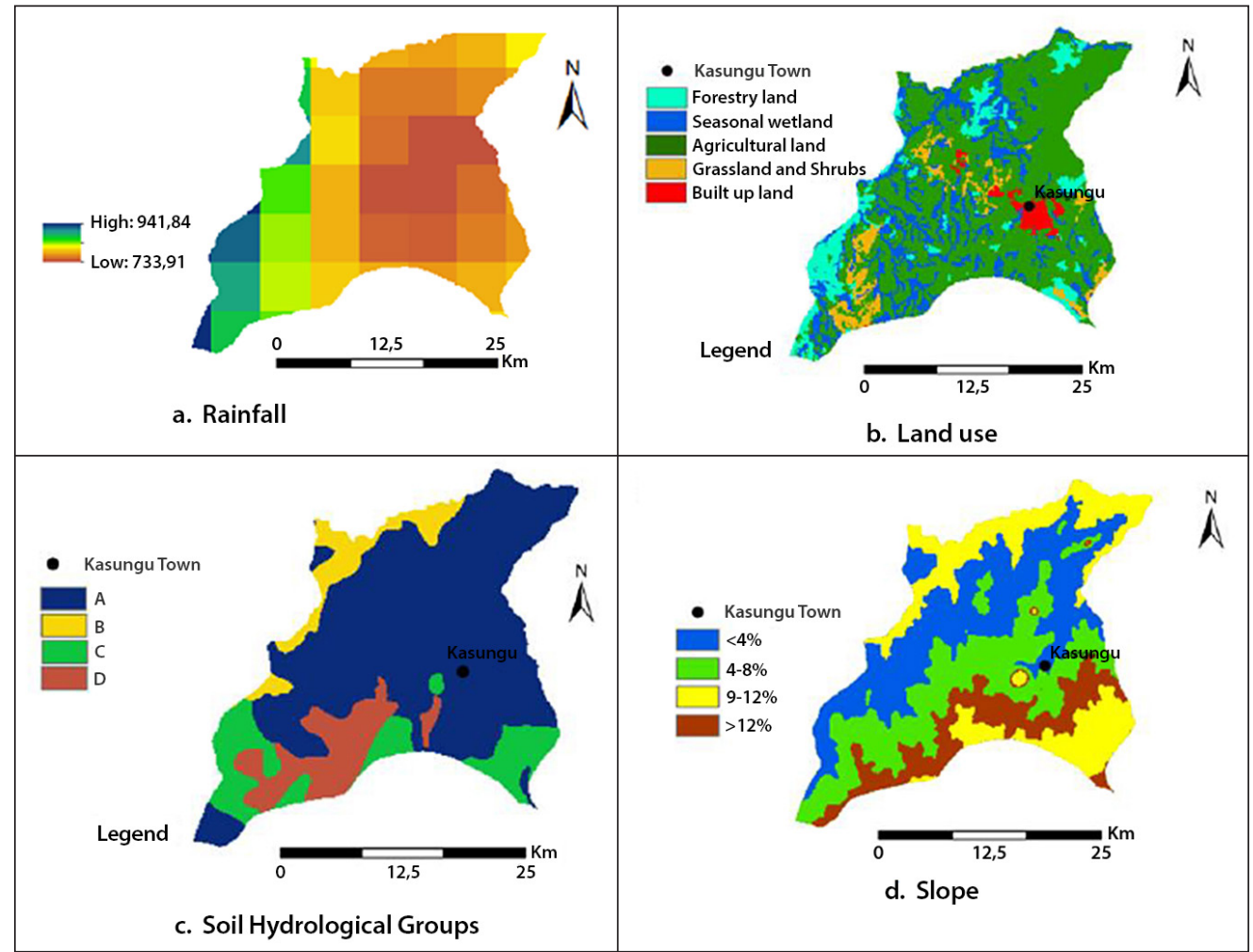

Figure 4. Physical factors 


\section{Environmental factors}

The environmental sensitivity map for Kasungu District (Kasungu SEP, 2013), which indicates how sensitive an area is to being affected by any environmental activity, was clipped using the study area boundary map and classified into 5 classes: very high, high, moderate, low and marginal, based on criteria used by Mwenge Kahinda et al. (2008). In their study they used environmental factors such as the Ecological Importance and Sensitivity Category (EISC). Ecological sensitivity (or fragility) refers to the system's capacity to resist disturbance and to recover from disturbance once it has occurred (resilience), as shown in Fig. 5b. In Malawi, a piece of land is allocated a class based on the anticipated negative effects per $500 \mathrm{~m}^{2}$ land, due to agricultural activities, on the biodiversity in terms of deprivation of required amount of water for survival. In this study environmental factors were grouped into 5 classes, namely, very high, high, moderate, low and marginal. A 'very high' environmental class indicates that the biodiversity is very sensitive to environmental modifications, and hence least suited for RWH, as shown in Table 2.

\section{Integrating factors in a GIS platform}

\section{Rainfall-runoff modelling}

The SCS-CN method was used to estimate the amount of runoff generated in the area. Finally, a runoff potential map was generated and incorporated into the GIS model for identification of suitable sites for RWH. Land use and soil shape files were converted from vector format to raster using the conversion tools in ArcGIS 10.2.2 computer software. The soil map was reclassified into the Hydrological Soils Groups (HSG) of A, B, C, and D, as illustrated by Schulze et al. (1992), in order to conform to the values assigned by the look-up tables of Soil Conservation Service (Benimana et al., 2014). Assigned soil groups were as follows: Group A - sand, loamy sand and sandy loam types of soils; Group B - silt, silt loam and loam soils; Group C - sandy clay loam soils, and Group D - clay loam, silty clay loam, sandy clay, silty clay and clay soils. Concepts used for deriving curve number $(\mathrm{CN})$ by the SCS method provided the basis for generating $\mathrm{CN}$ for this study. Thus, based on the HSG land use output map, $\mathrm{CN}$ values were assigned to each combination following the procedures illustrated by the Soil Conservation Service (SCS, 1964). The chart in Fig. 6 shows the overall methodology for the GIS-based SCS-CN method which was adopted from Shadeed and Almasri (2010). The runoff depths for the different parts of the study area were determined using CHIRPS rainfall data, which generated the runoff potential map as shown in Fig. 7.

The amount of runoff harvested should be able to satisfy crop water requirements for each crop, e.g., maize, and too much or too little runoff is considered not suitable for RWH (Winnaar et al, 2007). Using a similar approach to Winnaar et al. (2007), the amount of runoff generated in the study area was classified into 5 groups, as shown in Table 3.

\section{Generation of RWH suitability map}

A suitability map was produced in a suitability model builder of ArcGIS 10.2.2. The model produces RWH suitability maps by incorporating various factor map layers using multi-criteria evaluation (MCE). Several tools of ArcGIS were built into the model to solve various spatial challenges, which included reclassifying values, re-projecting, and overlaying. All vectortype format maps were converted into raster datasets to enable the ArcGIS weighted overlay. A weighted linear combination (WLC) of MCE is standardized to a common numeric range, and then summed by means of a weighted average. All factors were combined by using a weight to each factors followed by a summation of the results to generate a suitability map calculated using Eq. 1 (Malczewski, 2004):
Table 2. RWH suitability ranking for environmental factors

\begin{tabular}{lcc}
\hline No. & Environmental sensitivity & Suitability score \\
\hline 1 & Marginal & 5 \\
2 & Low & 4 \\
3 & Moderate & 3 \\
4 & High & 2 \\
5 & Very High & 1 \\
\hline
\end{tabular}

Table 3. Suitability ranking for runoff potential areas

\begin{tabular}{cccc}
\hline No. & $\begin{array}{c}\text { Runoff generated } \\
\text { (mm/year) }\end{array}$ & $\begin{array}{c}\text { Runoff generation } \\
\text { potential }\end{array}$ & $\begin{array}{c}\text { RWH suitability } \\
\text { score }\end{array}$ \\
\hline 1 & $<328$ & Very low & 1 \\
2 & $328-473$ & Low & 2 \\
3 & $473-617$ & Medium & 3 \\
4 & $617-761$ & High & 4 \\
5 & $>761$ & Very high & 5 \\
\hline
\end{tabular}

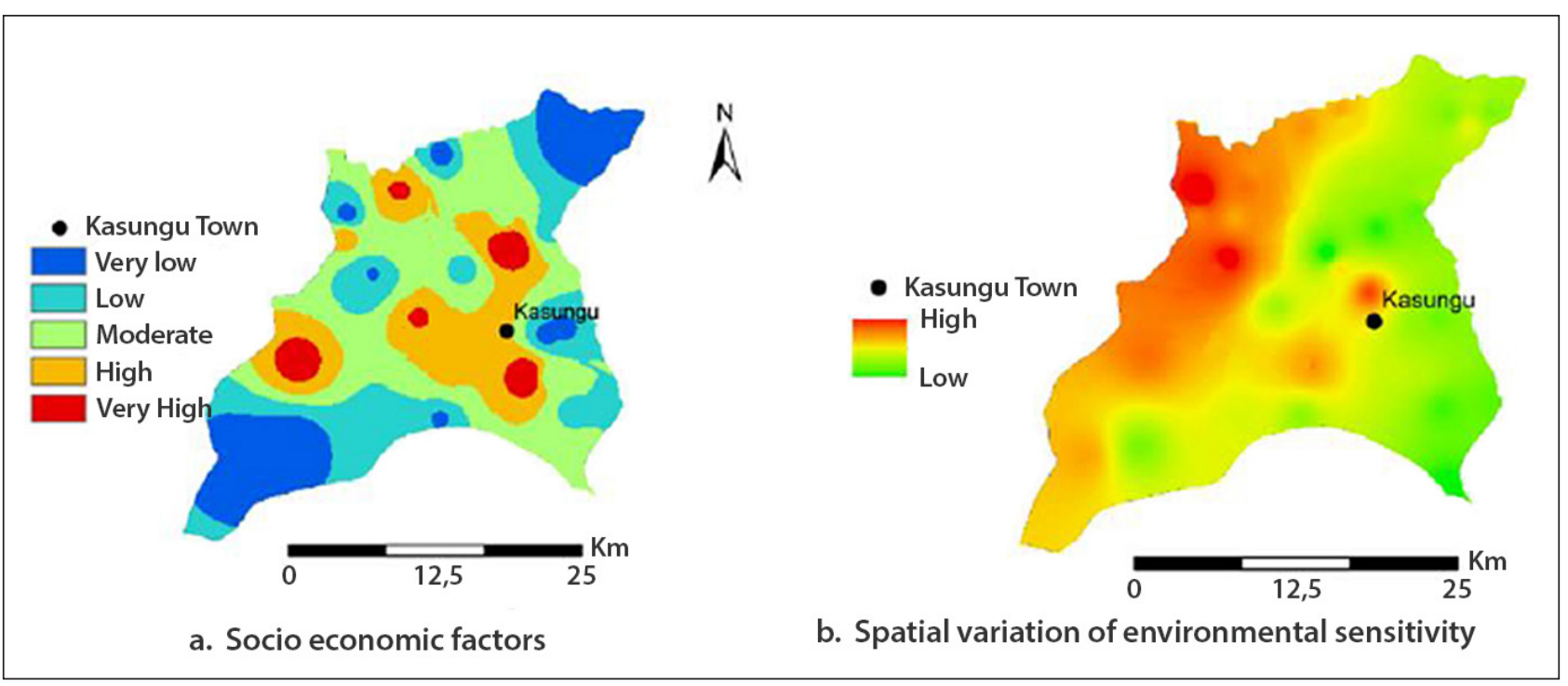

Figure 5. Socio-economic and environmental factors 


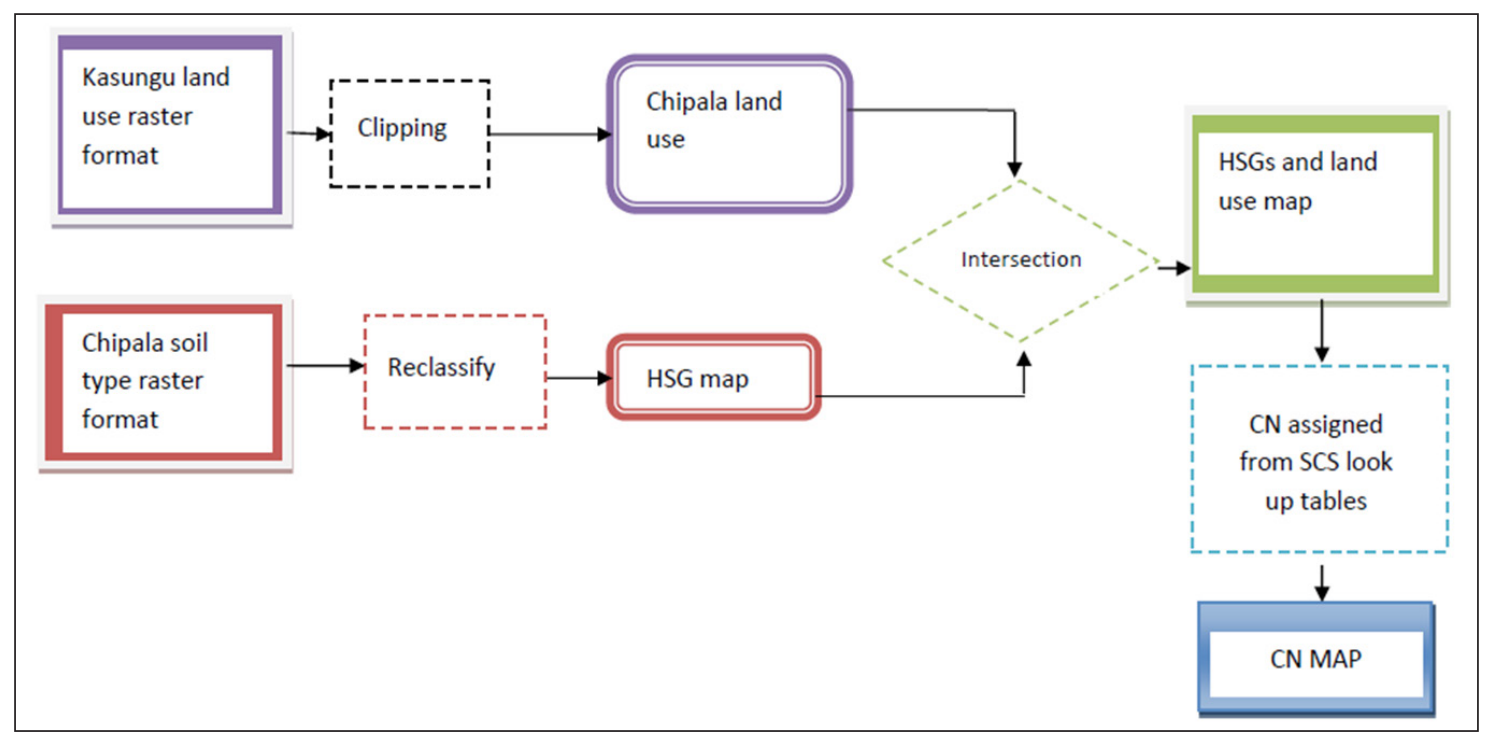

Figure 6. Methodology for deriving curve numbers (CN), adapted from Shadeed and Almasri (2010)

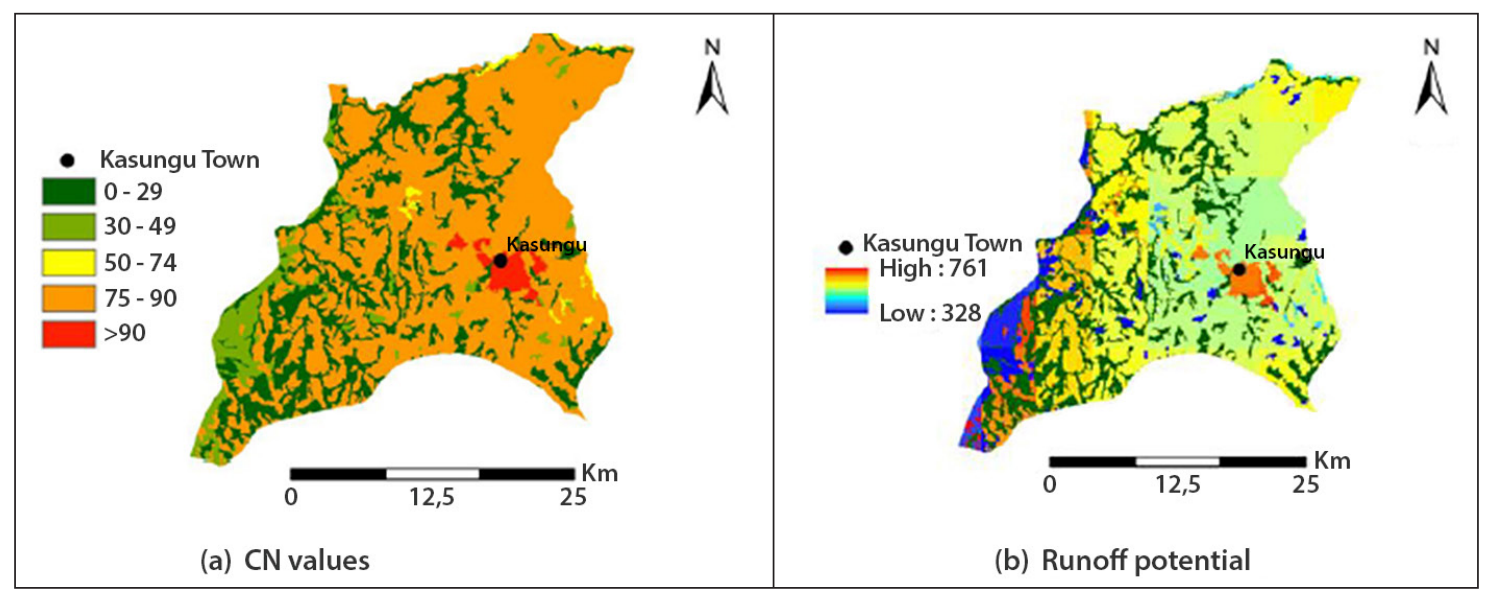

Figure 7. Curve number (CN) and runoff potential for the study area

$s=\sum W i X i$

where

$S=$ suitability output level per pixel ${ }_{i}$

$W_{i}=$ weight of factor $_{i}$

$X_{i}=$ criterion score of factor $_{i}$

Therefore, the higher the suitability value $S$ of a given site (pixel) $i$, the more suitable the pixel is for RWH technologies. $S$ is based on the established suitability ranking of $1-5$ where 1 denotes the sites (pixels) that are not suitable and 5 indicates areas (pixels) that are very highly suitable for RWH shown in Table 4.

The factor maps were re-classed into 5 comparable units, i.e., suitability classes, namely: 5 (very high suitability), 4 (high suitability), 3 (medium suitability), 2 (low suitability), and 1 (verylow suitability).

Table 4. Suitability ranking for S-value per pixel

\begin{tabular}{lcc}
\hline No. & Suitability class & Suitability score \\
\hline 1 & Very low & 1 \\
2 & Low & 2 \\
3 & Medium & 3 \\
4 & High & 4 \\
5 & Very high & 5 \\
\hline
\end{tabular}

This ranking system was selected because it has been used in many studies (Ketsela, 2009; Malczewski, 2004; Mbilinyi et al., 2007; Mwenge Kahinda et al., 2008; Munyao, 2010; Oweis et al., 1998; Singh et al., 2008) and it been found to be vigorous and reliable (Mahmoud and Alazba, 2014).

Multi-criteria evaluation (MCE) was used to create an output layer (final RWH suitability map) by combining different factors. Applying the analytical hierarchy process (AHP) and rank sum methods developed by Saaty (2008) in order to make a decision based on set priorities and to enable selection among the factors, weights were assigned to the factors. Thus, runoff potential was 0.6391 , socio-economic was 0.0687 and environmental was 0.2922 . The following steps are involved in AHP:

- Defining the decision-making goal.

- Selection, organization, and determination of the weighting factors.

- Applying the weighting factors to alternatives and ranking alternatives.

- Conducting sensitivity analysis.

\section{RESULTS AND DISCUSSION}

The field survey showed that various types of RWH technologies were implemented in the study area, with the most common technologies being soil mulching (50\%) and contour tied ridges (39\%). The other technologies were planting pits (7\%) and infiltration pits (4\%). Farmers indicated that soil mulching was the most preferred 
technology because it is cheaper in terms of investment cost and demands less labour as compared to other technologies. Infiltration pits were the least implemented technology because of high labour demand in the excavation of pits. The highest soil moisture observed from the field showed that mulching had moisture content of $42 \%$, while contour tied ridging had $36.2 \%$ and the control field $17.9 \%$. A similar trend was generally observed throughout the rain period as shown in Fig. 8. The average amount of soil moisture for all the fields during the season was highest under soil mulching (24.4\%), followed by contour tied ridging (22.2\%), while the control fields had the lowest (11.4\%).

It was shown that there was a variation in the soil moisture content achieved for the three technologies, as shown in Table 5. The ANOVA test showed significant variation of soil moisture under RWH technologies of contour tied ridging (4-36\%), soil mulching (5-40\%) and control fields with no RWH technologies (5-20\%), $(p=0.016,0.021$ and 0.007$)$. The ANOVA results showed that there was a statistically significant difference in the moisture measurements for the three technologies at $p<0.05$.
The results agree with studies by Mhizha and Ndiritu (2013) and Mupangwa et al. (2011) in Zimbabwe which reported that contour ridging improves soil moisture. Therefore, contour tied ridging and soil mulching retained soil moisture much better than fields without RWH technologies. This is in agreement with the field survey results on farmers' perceptions of RWH technologies, but did not reveal that mulching leads to higher moisture retention than contour tied ridging.

The generated suitability map in Fig. 9 indicates 5 classes of suitability; very high, high, moderate, marginal and not suitable. From the generated suitability map for the study area it was shown that $1.6 \mathrm{~km}^{2}, 260.6 \mathrm{~km}^{2}, 434.9 \mathrm{~km}^{2}, 78.6 \mathrm{~km}^{2}$ and $2.3 \mathrm{~km}^{2}$ of land, respectively, were very highly, highly, moderately, marginally and not suitable for in-field RWH (Table 6). The suitability map (Fig. 9) shows that the most suitable area for in-field RWH technologies lies to the north-eastern and south-western part of the study area. This is mainly because this area receives annual rainfall in the ranges of 700-900 $\mathrm{mm}$ and is characterised by patches of sandy loam soils, with gentle slopes of $2-8 \%$.

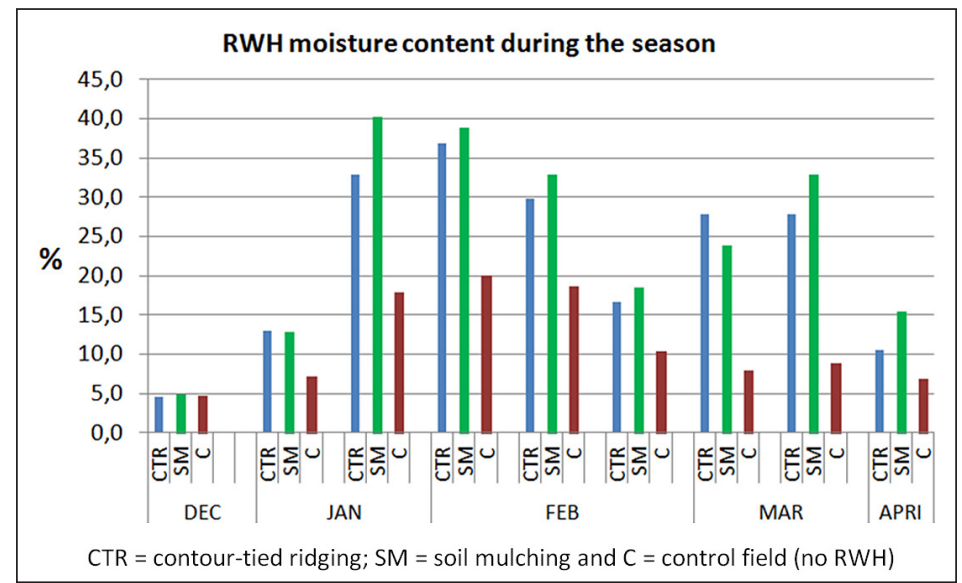

Figure 8. Soil moisture content under different RWH technologies

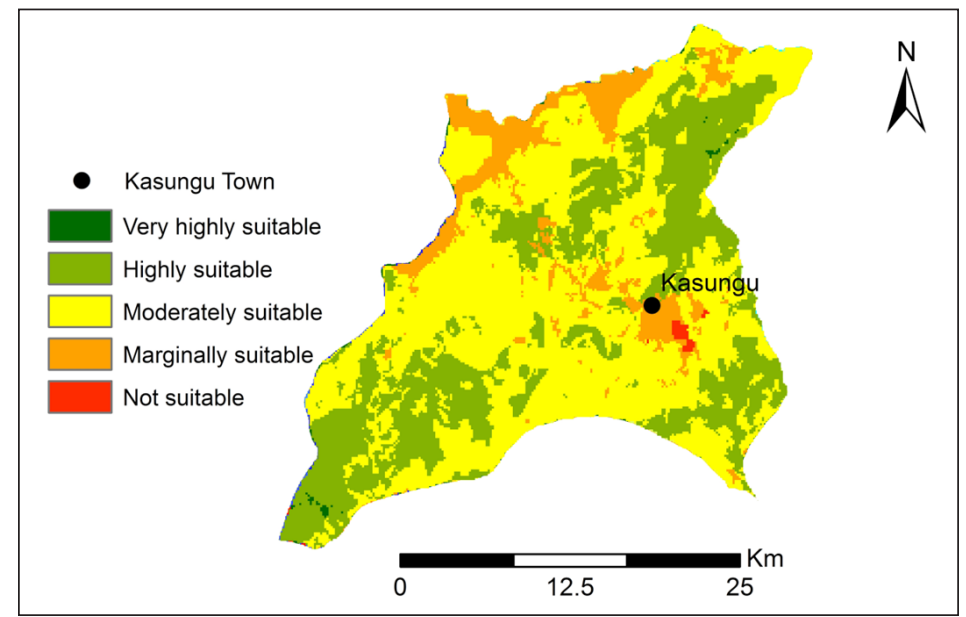

Figure 9. Rainwater harvesting suitability for the study area

Table 5. Variation in moisture content among technologies

\begin{tabular}{lcccc}
\hline Technology & \multicolumn{4}{c}{ Soil moisture content } \\
\cline { 2 - 5 } & Number & $\begin{array}{c}\text { Mean } \\
(\%)\end{array}$ & $\begin{array}{c}\text { Std. } \\
\text { deviation }\end{array}$ & $\begin{array}{c}\text { Coefficient of } \\
\text { variance (CV) }\end{array}$ \\
\hline Soil mulching & 9 & 22.2 & 11.3 & 0.51 \\
Contour tied ridging & 9 & 21.4 & 12.4 & 0.58 \\
Control fields & 9 & 11.4 & 5.8 & 0.51 \\
Average & & 19.3 & 10.3 & \\
\hline
\end{tabular}

Table 6. Area covered by RWH suitability classes

\begin{tabular}{lcc}
\hline Suitability class & Area $\left(\mathrm{km}^{2}\right)$ & Area percentage \\
\hline Very highly suitable & 1.6 & 0.2 \\
Highly suitable & 260.6 & 33.5 \\
Moderately suitable & 434.9 & 55.9 \\
Marginally suitable & 78.6 & 10.1 \\
Not suitable & 2.3 & 0.3 \\
Total & 778.0 & 100 \\
\hline
\end{tabular}




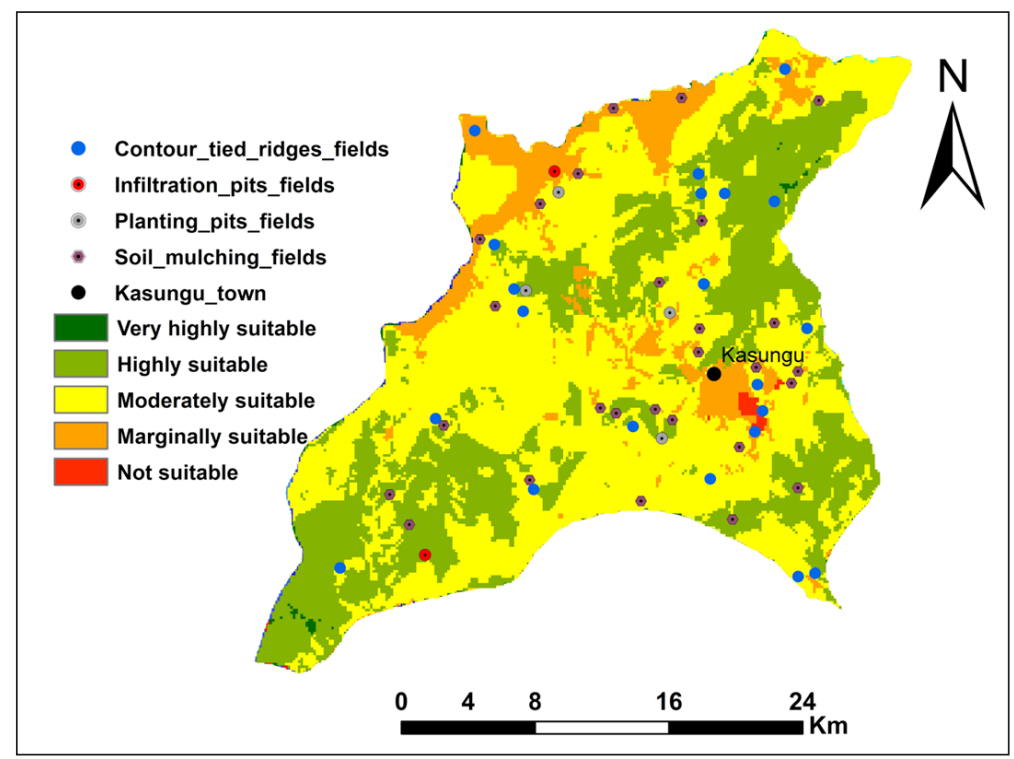

Figure 10. Location of existing RWH technologies under established suitability rank

Table 7. Comparisons of RWH technology actual locations and suitability levels

\begin{tabular}{lccccc}
\hline \multirow{2}{*}{$\begin{array}{l}\text { RWH } \\
\text { technologies }\end{array}$} & \multicolumn{5}{c}{ Level of suitability } \\
\cline { 2 - 6 } & Very high & High & Moderate & Low & Very low \\
\hline $\begin{array}{l}\text { Contour tied } \\
\text { ridging }\end{array}$ & 0 & 13 & 4 & 2 & 2 \\
Soil mulching & 0 & 14 & 7 & 6 & 0 \\
Pit planting & 0 & 2 & 2 & 0 & 0 \\
Infiltration pits & 0 & 1 & 1 & 0 & 0 \\
Total & 0 & 30 & 14 & 8 & 2 \\
Percentage & 0 & 55 & 26 & 15 & 4 \\
\hline
\end{tabular}

\section{Verification of the suitability model}

In order to assess for applicability of the suitability model (MCE tool in Arc Map 10.2.2), the location of the suitability levels obtained by the model were compared with the locations of existing RWH technologies. The results shown in Table 7 and in Fig. 10 indicate that 55\% of existing RWH technologies were located in the areas of high suitability, $26 \%$ in the areas of moderate suitability, $15 \%$ in low suitability areas and only $4 \%$ were located in areas classified as not suitable. Thus, the modelled suitability ranks align with the experiences and local knowledge of farmers. This method of verifying a model for identifying suitable RHW areas has been used in other studies (Ketsela, 2009; Mbilinyi et al., 2014).

\section{CONCLUSION}

This study aimed to identify and assess the performance of rainwater harvesting (RWH) systems in Kasungu District of Malawi, and to establish a GIS-based model for locating suitability areas for the District. Contour tied ridges and mulching were found to be the most commonly implemented RWH technologies in the District. The adoption of these technologies was attributed to their simplicity and low cost. These technologies were found to provide satisfactory levels of water retention for the crops during the dry spells. Several factors, including annual rainfall, soil texture, soil depth, slope and land use, socio-economic and environmental parameters were considered to influence RWH suitability and were applied in the modelling. The integration of the factors for locating suitable areas of RWH technologies was done in a GIS-based platform in order to generate suitability maps using the Arc GIS 10.2.2 model builder. This model used a multi- criteria evaluation that integrated the different factors through a weighted overlaying process. The generated suitability map for infield RWH technologies indicated that the majority of the land was moderately suitable (56\%) and highly suitable (34\%). These results were verified using information that was obtained from a field survey, which showed that $55 \%$ of the RWH technologies were located in areas modelled as having high suitability, 26\% in areas of moderate suitability, $15 \%$ in areas of low suitability and $4 \%$ in areas modelled as unsuitable. These results revealed a satisfactory reliability and accuracy of the modelling because most of the RWH sites were located in the areas of predicted high and moderate suitability.

\section{RECOMMENDATIONS}

The results of the models revealed that there is high rainwater harvesting potential in Kasungu District and, if optimally harvested, the local farm water demand for crops could be achieved. The framework of this study could be adopted in research and practice to plan and manage future rainwater harvesting activities or projects in Malawi and other countries in the region. The study approach could be refined in future studies by including more social-ecological factors in the model.

\section{ACKNOWLEDGEMENTS}

The authors would like to thank WaterNet for providing the resources for conducting the study, as well as the farmers and office of Kasungu District Council, for providing useful information for the study.

\section{REFERENCES}

ATKINSON R and FLINT J (2001) Accessing hidden and hard-to-reach populations: Snowball research strategies. Social Research Update vol. 33.

BAIYEGUNHI LJS (2015) Determinants of rainwater harvesting technology (RWHT) adoption for home gardening in Msinga, KwaZulu-Natal, South Africa. Water SA. 41 33-40. https://doi.org/ 10.4314/wsa.v41i1.6

BENIMANA JC, WALI UG, NHAPI I, ANYEMEDU FOK and GUMINDOGA W (2014) Rainwater harvesting potential for production in the Bugesera district of Rwanda. Afr. J. Agric. Res. 10 (19) 2020-2031. https://doi.org/10.5897/AJAR12.820

BLACK CA (1965) Methods Of Soil Analysis: Part I, Physical and Mineralogical Properties. American Society of Agronomy, Madison, Wisconsin. https://doi.org/10.2134/agronmonogr9.1 
BURAIHI FH and SHARIFF ARM (2015) Selection of rainwater harvesting sites by using remote sensing and GIS techniques: A case of Kirkuk. Iraq J. Sci. Eng. 76 75-81. https://doi.org/10.11113/ jt.v76.5955

BURROUGH P (2000) Principles of Geographical Information Systems for Land Resources Assessment. Clarendon Press, Oxford.

CRITCHLEY W, SIEGERT K and CHAPMAN C (1991) Water Harvesting Manual. FAO Paper MISC/17/ 91. GSO, Rome. 133 pp.

DE WINNAAR G, JEWITT GPW and HORAN M (2007) AGIS-based approach for identifying potential runoff harvesting sites in the Thukela River basin, South Africa. Phys. Chem. Earth. 32 1058-1067. https://doi.org/10.1016/j.pce.2007.07.009

DOORENBOS J and PRUITT OW (1977) Guidelines for predicting crop water requirements. FAO Irrigation and Drainage. FAO, Rome. $24 \mathrm{pp}$.

FACE OF MALAWI (2013) Malawi farmers adopt rain-water harvesting technologies. URL: http://www.faceofmalawi.com/2013/03/ma awi-farmers-adopt-rain-water-harvesting-technologies (Accessed 15 January 2016).

FAO (2003) Land and Water Digital Media Series, 26. Planning of Water Harvesting Schemes, Unit 22. FAO, Rome.

JASROTIA AS, MAJHI A and SINGH S (2009) Water balance approach for rainwater harvesting using remote sensing and GIS techniques, Jammu Himalaya, India. Water Resour. Manage. 23 3035-3055. https://doi.org/10.1007/s11269-009-9422-5

JEDHE YS (2014) Runoff map preparation for Khadakwasla using ArcCN runoff tool. Int. J. Sci. Technol. 12 13-17.

JHA MK, CHOWDARY VM and KULKARNI Y (2014) Rainwater harvesting planning using geospatial techniques and multicriteria decision analysis. Resour. Conserv. Recycl. 83 96-111. https://doi. org/10.1016/j.resconrec.2013.12.003

KADAM A, KALE S, PAWAR N, SANKHUA R and PAWAR N (2012) Identifying potential rainwater harvesting sites of a semiarid,basaltic region of Western India, using SCS-CN method. Water Resour. Manage. 26 2537-2554. https://doi.org/10.1007/s11269-0120031-3

KASUNGU SEP (2013) Kasungu District Socio Economic Profile. Awina Publishers, [Kasungu] (ISSN 6789).

KASUNGU SEP (2009) Kasungu District Socio Economic Profile. Awina Publishers, [Kasungu] (ISSN 2617).

KATSANOS D, RETALIS A and MICHAELIDES S (2016) Validation of a high-resolution precipitation database ( CHIRPS ) over Cyprus for a 30 -year period. Atmos. Res. 169 459-464. https://doi.org/10.1016/j. atmosres.2015.05.015

KETSELA GM (2009) Identification of potential rain water harvesting areas. Central Rift Valley of Ethiopia using a GIS based methodology. Wageningen University, The Netherlands.

MAHMOUD SH and ALAZBA AA (2014) The potential of in situ rainwater harvesting in arid regions. Arab. J. Geosci. 8 5167-5179. https://doi.org/10.1007/s12517-014-1535-3

METMALAWI (2006) Malawi Meterological Services. URL: http:// www.metmalawi.com (Accessed 21 October 2016).

MALCZEWSKI J (2004) GIS-based land-use suitability analysis: a critical overview. Prog. Plann. 62 3-65. https://doi.org/10.1016/j. progress.2003.09.002

MBILINYI B, TUMBO S and MAHOO H (2007) GIS-based decision support system for identifying potential sites for rainwater harvesting. Phys. Chem. Earth. 32 1074-1081. https://doi.org/10. 1016/j.pce.2007.07.014

MBILINYI BP, TUMBO SD, MAHOO HF and MKILAMWINYI F (2014) Identification of suitable indices for identification of potential sites for rainwater harvesting. Tanzania J. Agric. Sci. 12 35-46.

MHIZHA A and NDIRITU JG (2013) Assessing crop yield benefits from in situ rainwater harvesting through contour ridges in semi-arid Zimbabwe. Phys. Chem. Earth. 66 123-130. https://doi.org/10.1016/j. pce.2013.09.008
MLOZA-BANDA H (2006) Experiences with micro agricultural water management technologies: Malawi. Report submitted to the International Water Management Institute (IWMI) Southern Africa Sub-regional Office, Pretoria.

MUNYAO JN (2010) Use of satellite products to assess water harvesting potential in remote areas of Africa: a case study of Unguja Island, Zanzibar. International Institute of Geo-information Science and Earth Observation Science and Earth Observation, The Netherlands.

MUPANGWA W, TWOMLOW S and WALKER S (2011) Dead level contours and infiltration pits for risk mitigation in smallholder cropping systems of southern Zimbabwe. Phys. Chem. Earth. 47-48 166-172. https://doi.org/10.1016/j.pce.2011.06.011

MWENGE KAHINDA J, LILLIE ES, TAIGBENU AE, TAUTE M and BOROTO RJ (2008) Developing suitability maps for rainwater harvesting in South Africa. Phys. Chem. Earth Parts A/B/C. 33788 799. https://doi.org/10.1016/j.pce.2008.06.047

MWENGE KAHINDA J, TAIGBENU AE and SEJAMOHOLO BBP (2009) A GIS-based decision support system for rainwater harvesting (RHADESS). Phys. Chem. Earth. 34 767-775. https://doi.org/ 10.1016/j.pce.2009.06.011

MZIRAI OB and TUMBO SD (2010) Macro-catchment rainwater harvesting systems. Challenges and opportunities to access runoff. J. Anim. Plant Sci. 7 789-800.

NSO (National Statistical Office of Malawi) (2000). Census of Population and Housing Report. National Statistical Office of Malawi, Lilongwe, Malawi.

NTHARA M (2020) Rainwater harvesting for improved food security and environmental conservation; Experiences from Malawi. In: Espíndola JAG, Flores CAC; Pacheco-Vega R and Montes MRP (eds) International Rainwater Catchment Systems Experiences: Towards Water Security. https://doi.org/10.2166/9781789060584

NTHUNI SM, TILLMANN L and GERTRUD S (2014) Modelling the potential of rainwater harvesting in western Kenya using remote sensing and GIS techniques. Karlsruhe University of Applied Sciences, Faculty of Information Management and Media, Moltkestrasse 30, D-76133 Karlsruhe, Germany.

OWEIS T, PRINZ D and OBERLE A (1998) Rainwater harvesting for dry land agriculture - developing a methodology based on remote sensing and GIS. In: Proceedings, XIII International Congress Agricultural Engineering. 10 21-34. Rabat, Morocco.

PALLANT J (2013) SPSS Survival Manual, 5TH Edition, Buckingham, Open University Press. Available http://www.academia.dk/Biolo giskAntropologi/Epidemiologi/PDF/SPSS_Survival Manual_Ver12. pdf (Accessed 2 July 2016)

ROCKSTRÖMJ and FALKENMARKM (2015) Increase water harvesting in Africa. Nature. 283-285. https://doi.org/10.1038/519283a

SAATY T (2008) Decision making with analytic hierarchy process. Int. J. Serv. Sci. 1 16-19. https://doi.org/10.1504/IJSSCI.2008.017590

SCHIARITI P (2012) Basic hydrology - runoff curve numbers. Mercer County Soil Conservation District, Mercer County, Califonia.

SCHULZE RE, SCHMIDT EJ and SMITHERS JC (1992) SCS-SA User manual PC based SCS design flood estimates for small catchments in Southern Africa. Department of Agricultural Engineering, University of Natal, Pietermaritzburg.

SHADEED S and ALMASRI M (2010) Application of GIS-based SCSCN method in West Bank catchments, Palestine. Water Sci. Eng. 3 1-13.

SINGH JP, SINGH D and LITORIA PK (2008) Selection of suitable sites for water harvesting structures in Soankhad Watershed. Indian Soc. Remote Sens. 37 21-35. https://doi.org/10.1007/s12524-009-0009-7

SOIL CONSERVATION SERVICE (USDA-NRCS) (1964) National Engineering Handbook, Section 4, Hydrology. Department of Agriculture, Washington. 450 pp. 